\title{
Analisis Kesehatan Perbankan Pada PT. Bank Rakyat Indonesia (Persero) Tbk.
}

\author{
Asmaul Husna ${ }^{1}$, Rismansyah ${ }^{2}$, Panca Satria Putra ${ }^{3}$ \\ ${ }^{1}$ Fakultas Ekonomi dan Bisnis Universitas PGRI Palembang, asmaulh116@gmail.com \\ ${ }^{2}$ Fakultas Ekonomi dan Bisnis Universitas PGRI Palembang, rismansyah1972@gmail.com \\ ${ }^{3}$ Fakultas Ekonomi dan Bisnis Universitas PGRI Palembang, pancadahlan1@gmail.com
}

\begin{abstract}
ABSTRAK
Penelitian ini bertujuan untuk mengetahui kesehatan perbankan PT Bank Rakyat Indonesia (Persero) Tbk. dengan menggunakan metode RGEC (Risk Profile, Good Corporate Governance, Earnings, Capital) secara keseluruhan pada periode 2014-2018 dan sesuai dengan Peraturan Bank Indonesia No. 13/1/PBI/2011 dan Surat Edaran Bank Indonesia No.13/24/DPNP/2011. Penelitian ini merupakan penelitian deskriptif kuantitatif menggunakan perhitungan metode RGEC. Penilaian Risk Profile (Resiko Profil) menggunakan resiko likuiditas yaitu rasio LDR dan resiko kredit yaitu rasio NPL. Penilaian Earnings (Rentabilitas) menggunakan ROA, NIM dan BOPO. Sedangkan untuk Capital (Permodalan) penilaiannya menggunakan (CAR). Hasil penelitian kesehatan perbankan PT Bank Rakyat Indonesia (Persero) Tbk. selama tahun 2014-2018 menunjukkan bahwa Indikator Risk Profile dari tahun ke tahun dengan nilai LDR berturut-turut 79,56\%, 84,38\%, 85,28\%, 85,42\% dan 86,84\% dengan kategori Sehat dan Cukup Sehat. Kemudian nilai NPL berturut-turut 1,26\%, 1,17\%, 1,06\%, $1,10 \%$ dan 1,17\% dengan kategori Sangat Sehat. Indikator Earnings dari tahun ke tahun dengan nilai ROA berturut-turut 3,84\%, 3,70\%,3,39\%, 3,28\% dan 3,22\% dengan kategori Sangat Sehat. Kemudian nilai NIM yaitu berturut-turut sebesar 7,07\%,7,45\%,6,60\%,6,47\% dan $6,59 \%$ dengan kategori Sangat Sehat. Dan nilai BOPO yaitu berturut-turut sebesar 45,88\%, 56,83\%, 59,18\%, $60,54 \%$ dan 59,66\% dengan kategori Sangat Sehat. Indikator Capital yaitu CAR berturut-turut dengan kategori Sangat Sehat dimana memperoleh nilai dari tahun ke tahun yaitu 20,87\%, 21,06\%, 23,65\%, $23,85 \%$ dan $22,63 \%$. Berdasarkan seluruh aspek penilaian RGEC diperoleh kesehatan PT Bank Rakyat Indonesia (Persero) Tbk. dalam kondisi Sangat Sehat dengan peringkat komposit 1, dimana nilai yang diperoleh berturut-turut adalah 96,66\%, 96,66\%, 96,66\%, 93,33\%, 93,33\%.
\end{abstract}

Kata Kunci : BRI, Kesehatan Bank, Metode RGEC.

\begin{abstract}
This study aims to determine the banking health of PT Bank Rakyat Indonesia (Persero) Tbk. by using the overall RGEC (Risk Profile, Good Corporate Governance, Earnings, Capital) method in the 2014-2018 period and in accordance with Bank Indonesia Regulation No. 13/1 / PBI / 2011 and Bank Indonesia Circular Letter No 13/24 / DPNP / 2011. This research is a quantitative descriptive study using the RGEC calculation method. Risk Profile Assessment uses liquidity risk, namely LDR ratio and credit risk, namely NPL ratio Earnings (Rentability) uses ROA, NIM and BOPO. While for Capital (Capital), the assessment uses (CAR) The results of banking health research PT Bank Rakyat Indonesia ( Persero) Tbk. during 2014-2018 shows that Risk Profile Indicators from year to year with LDR values respectively $79.56 \%, 84.38 \%, 85.28 \%, 85.42 \%$ and $86.84 \%$ with the category of Healthy and Fairly Healthy . Then the NPL values are 1.26\%, 1.17\%, 1.06\%, 1.10\% and $1.17 \%$ with the category Very Healthy Indicators Earnings from year to year with ROA values respectively $3.84 \%$, $3.70 \%, 3.39 \%, 3.28 \%$ and $3.22 \%$ in the Very Healthy category. Then the NIM values are respectively $7.07 \%, 7.45 \%, 6.60 \%, 6.47 \%$ and $6.59 \%$ with the Very Healthy category. And the BOPO value is 45.88\%, 56.83\%, 59, 18\%, 60.54\% and 59.66\% respectively with the Very Healthy Capital Indicator category CAR which is in the Very Healthy category which scores from year to year namely $20.87 \%$, $21.06 \%, 23.65 \%, 23.85 \%$ and $22.63 \%$ Based on all aspects of RGEC assessment obtained the health of PT Bank Rakyat Indonesia (Persero) Tbk in a very healthy condition with a rating composite 1 , where the values obtained were $96.66 \%, 96.66 \%, 96.66 \%, 93.33 \%, 93.33 \%$.
\end{abstract}

Keywords: BRI, Bank Health, RGEC Method. 


\section{A. PENDAhULUAN}

Peran Bank sebagai wahana untuk menghimpun dan menyalurkan dana secara efektif dan efisien ke rakyat banyak guna meningkatkan taraf hidup. Di Indonesia banyak sektor-sektor usaha yang menggunakan bank sebagai mitra dalam menjalankan usahanya. Hampir semua sektor perbankan yang berhubungan dengan kegiatan keuangan selalu membutuhkan jasa bank. Dimasa yang akan datang setiap lembaga perbankan tidak dapat lepas dari dunia keuangan apabila ingin menjalankan kegiatan perekonomian (Dewi dan Candra Dewi, 2018:1596).

Dalam UU No.10 Tahun 1998 perbankan merupakan himpunan dana diberbagai sumber keuangan atau bank merupakan badan usaha yang menghimpun dana dari masyarakat dalam bentuk simpanan dan menyalurkannya ke masyarakat dalam bentuk kredit dan/atau bentuk-bentuk lainnya dalam rangka meningkatkan taraf hidup rakyat banyak. Maka dari itu setiap bank harus menjaga kondisi tingkat kesehatan. Dengan sehat nya suatu bank maka akan tercermin bahwa bank tersebut layak mendapatkan kepercayaan dari masyarakat maupun nasabah untuk memenuhi harapannya.

Penelitian ini mengambil objek pada PT Bank Rakyat Indonesia (Persero) Tbk. merupakan bank yang mempunyai size yang besar dan sejarah panjang dengan segmen UMKM, serta terjun ke perdesaan yang memiliki banyak program seperti bannyak bantuan, program KUR dll. Proram-program tersebut dilaksanakan untuk tujuan PT Bank Rakyat Indonesia (Persero) Tbk. juga senantiasa dapat memberikan kontribusi positif bagi perekonomian nasional, khususnya pada sektor ekonomi mikro. Adapun munculnya iklim persaingan antar bank yang semakin ketat mengharuskan Bank BRI untuk menerapkan tata kelola perusahaan yang baik.

Sebagai lembaga keuangan perbankan apakah BRI telah melakukan analisis keuangan sesuai aturan-aturan perusahaan secara baik dan benar sehingga dapat diketahui posisi keuangannya. Menilai kemampuan perbankan dalam pelaksanaan dan menjalankan kegiatan sehari-hari apakah BRI lebih efisien dan efektif dalam mengelola harta yang dimiliki dan juga menilai kemampuan bank untuk memperoleh keuntungan dari nasabah di suatu periode tertentu (Bachtiar, 2019:12)

Untuk mengetahui kondisi keuangan suatu bank, dapat dilihat dari laporan keuangan yang disajikan oleh suatu bank secara periodik. Laporan ini juga sekaligus menggambarkan kinerja bank secara periode tertentu. Laporan Keuangan yang disusun dengan baik dan akurat akan memberikan gambaran keadaan yang nyata melalui hasil dan prestasi yang sudah dicapai suatu bank dalam kurun waktu tertentu, keadaan inilah yang dapat digunakann untuk melihat kinerja dan kesehatan suatu bank.

Informasi laporan keuangan tersebut sangat lah penting untuk semua pihak yang membutuhkan. Diantaranya pihak intern bank, seperti manajemen bank dan pihak ekstern bank, seperti kreditur, pemerintah, pemegang saham dan masyarakat sebagai nasabah. Laporan keuangan diharapkan dapat berguna bagi pemakainya dalam menilai kesehatan suatu bank (Hery, 2015:2)

Purba (2019:201) Kesehatan bank adalah kemampuan suatu bank dalam melakukan aktivitas operasional perbankan secara normal dan mampu memenuhii seluruh kewajiban bank dengan cara-cara yang sesuai dengan peraturan perbankan yang berlaku. Untuk melakukan penilaian terhadap kesehatan dan prestasi bank, Bank Indonesia telah menetapkan metode penilaian tersendiri baik bank konvensional maupun non konvensional. 
Terdapat beberapa metode yang telah ditentukan dalam hal menilai kesehatan bank yang diatur oleh Bank Indonesia No. 13/1/PBI/2011 yaitu menggunakan metode pendekatan RGEC (Risk profile, Good corporate governance, Earning dan Capital). Metode ini berlaku sejak 1 Jabuari 2012. Yang sebelumnya menggantikan peraturan metode penilaian dengan pendekatan CAMEL (Capital , Asset quality, Manajement, Earning, Liquidity and Sensitivity to Market Risks) yang diatur pada peraturan Bank Indonesia PBI No.6/10/PBI/2004 (Saladin dan Hendri, 2017:1)

Lasta (2014:30) menunjukkan bahwa LDR pada Bank Rakyat Indonesia ditahun 2011 sampai 2013 mengalami penurunan. Meskipun LDR mengalami penurunan tetapi masih termasuk kedalam kategori cukup sehat dalam penilaian peringkat komposit kategori peringkat 3.

\section{B. KAJIAN TEORI}

\section{Bank}

UU No.10 tahun 1998 Perbankan merupakan himpunan dana dari berbagai sumber keuangan atau bank merupakan badan usaha atau lembaga penghimpun dana masyarakat dalam bentuk simpanan dan disalurkan kepada masyarakat dalam bentuk kredit dan atau bentuk lainnya dalam rangka meningkatkan taraf hidup rakyat banyak.

\section{Laporan Keuangan Bank}

Ismail (2010:15) laporan keuangan bank merupakan bentuk pertanggungjawaban manajemen terhadap pihak-pihak yang berkepentingan dengan kinerja bank yang dicapai selama periode tertentu.

\section{Kesehatan Bank}

Dalam pasal 1 Peraturan Bank Indonesia No 13/1/PBI/2011 tentang penilaian tingkat kesehatan bank umum yang dimaksud dengan tingkat kesehatan bank adalah hasil penilaian kondisi bank yang dilakukan terhadap risiko dan kinerja bank.

Purba (2019:201) kesehatan bank merupakan kemampuan suatu bank dalam melakukan kegiatan operasional perbankan secara normall dan mampu memenuhi seluruh kewajibannya dengan bank dengan cara-cara yang sesuai dengan peraturan perbankan yang berlaku. Untuk mengetahui sehat atau tidaknya suatu bank dapat dilihat dari kegiatan bank antara lain:

\section{Penilaian Kesehatan Bank dengan Metode RGEC}

Berdasarkan peraturan Bank Indonesia No.13/1/PBI/2011 tentang penilaian tingkat kesehatan bank umum, BI telah menetapkan sistem penilaian tingkat kesehatan bank berbasis resiko (RGEC) menggantikan CAMEL yang dahulu diatur dalam Peraturan Bank Indonesia Np.6/10/PBI 2004. Penilaian tingkat kesehata bank berbasis resiko (RGEC) diatur dalam Surat Edaran Bank Indonesia No.13/24/DPNP/2011 anggal 25 Oktober 2011 tentan kesehatan bank umum.

IBI (2016:12) tata cara penilaian kesehatan bank berbasis resiko (RGEC) meliputi:

\section{1) Penilaian profil resiko (Risk Profile)}

Penilaian terhadap resiko inheren dan kualitas penerapan manajemen resiko dalam aktivitas operasional bank. Resiko yang dapat dinilai terdiri atas 8 jenis resiko yaitu:
a. Resiko kredit,
b. resiko pasar, 

c. resiko likuiditas,
d. resiko operasional,
e. resiko hukum,
f. resiko strategis,
g. resiko kepatuhan dan
h. resiko reputasi.

Salah satu indikator yang digunakan dalam penelitian ini adalah resiko likuiditas adalah Loan to Deposit Ratio (LDR) dan resiko kredit adalah Non Perfoming Loan (NPL). Berikut ini penilaian peringkat komposit LDR dan NPL antara lain:

\section{$>$ Loan to Deposit Ratio (LDR)}

Kasmir (2015:319) LDR merupakan rasio untuk mengukur komposisi jumlah kredit yang diberikan terhadap jumlah dana masyarakat yang digunakan.

Berikut ini menurut SE BI No.13/30/DPNP tanggal 16 Desember 2011 tentang pedomaan rasio keuangan rumus LDR antara lain:

$$
\text { LDR }=\frac{\text { Total Kredit }}{\text { Dana Pihak Ketiga }} \times 100 \%
$$

Berikut ini kriteria untuk penilaian resiko likuiditas:

TABEL BOBOT PERINGKAT KOMPOSIT LDR

\begin{tabular}{|c|c|c|}
\hline Nilai Komposit & Peringkat & Predikat \\
\hline$<60 \%$ LDR $\leq 75 \%$ & 1 & Sangat Sehat \\
\hline $75 \%<$ LDR $\leq 85 \%$ & 2 & Sehat \\
\hline $85 \%<$ LDR $\leq 100 \%$ & 3 & Cukup Sehat \\
\hline $100 \%<$ LDR $\leq 110 \%$ & 4 & Kurang Sehat \\
\hline LDR $>110 \%$ & 5 & Tidak Sehat \\
\hline
\end{tabular}

Sumber: SE BI No.13/24/DPNP/2011

\section{Non Performing Loan (NPL)}

Merupakan rasio yang menunjukkan kemampuan manajemen dalam mengelola kredit bermasalah dari keseluruhan kredit yang diberikan oleh bank yang kolektibilitasnya kurang lancer, diragukan, dan macet dari kredit yang diberikan secara keseluruhan.

Berikut ini menurut SE BI No.13/30/DPNP tanggal 16 Desember 2011 tentang pedomaan rasio keuangan rumus NPL antara lain :

$$
\text { NPL }=\frac{\text { Kredit Bermasalah }}{\text { Total Kredit }} x 100 \%
$$

Berikut ini kriteria untuk penilaian resiko kredit:

TABEL BOBOT PERINGKAT KOMPOSIT NPL

\begin{tabular}{|c|c|c|}
\hline Nilai Komposit & Peringkat & Predikat \\
\hline$\leq 2 \%$ & 1 & Sangat Sehat \\
\hline $2 \%<\mathrm{NPL}<5 \%$ & 2 & Sehat \\
\hline $5 \% \leq \mathrm{NPL} \leq 8 \%$ & 3 & Cukup Sehat \\
\hline $8 \% \leq \mathrm{NPL} \leq 12 \%$ & 4 & Kurang Sehat \\
\hline $\mathrm{NPL}>12 \%$ & 5 & Tidak Sehat \\
\hline
\end{tabular}

Sumber: SE BI No.13/24/DPNP/2011 


\section{2) Penilaian Rentabilitas (Earning)}

Meliputi penilaian terhadap kinerja pendapatan atau earning, sumber-sumber pendapatan, serta penilaian apakah pendapatan bank itu bersifat berkelanjutan. Salah satunya indikator penilaian yang dapat digunakan adalah Return On Asset (ROA), Net Interest Margin ( NIM) dan Beban Operasional terhadap Pendapatan Operasional (BOPO). Berikut ini penilaian peringkat komposit ROA, NIM dan BOPO antara lain:

\section{Return On Asset (ROA)}

Fahmi (2012:98) ROA adalah melihat sejauh mana investasi yang telah ditanamkan mampu memberikan pengembalian keuntungan sesuai dengan yang diharapkan dan investasi tersebut sebenarnya sama dengan asset perusahaan yang ditempatkan.

Berikut ini menurut SE BI No.13/30/DPNP tanggal 16 Desember 2011 tentang pedomaan rasio keuangan rumus $\mathrm{ROA}$ antara lain:

Berikut ini kriteria untuk penilaian ROA:

$$
\mathrm{ROA}=\frac{\text { Laba sebelum pajak }}{\text { Rata }- \text { rata total assets }} \times 100 \%
$$

\section{TABEL BOBOT PERINGKAT KOMPOSIT ROA}

\begin{tabular}{|c|c|c|}
\hline Nilai Komposit & Peringkat & Predikat \\
\hline$>1,5 \%$ & 1 & Sangat Sehat \\
\hline $1,25 \%<\mathrm{ROA} \leq 1,5 \%$ & 2 & Sehat \\
\hline $0,5 \%<\mathrm{ROA} \leq 1,25 \%$ & 3 & Cukup Sehat \\
\hline $0 \%<\mathrm{ROA} \leq 0,5 \%$ & 4 & Kurang Sehat \\
\hline ROA $\leq 0 \%$ & 5 & Tidak Sehat \\
\hline
\end{tabular}

Sumber: SE BI No.13/24/DPNP/2011

\section{Net Interest Margin (NIM)}

Berikut ini menurut SE BI No.13/30/DPNP tanggal 16 Desember 2011 tentang pedoman rasio keuangan rumus NIM antara lain:

$$
\mathrm{NIM}=\frac{\text { Pendapatan bunga bersih }}{\text { Rata }- \text { rata Aktiva Produktif }} \times 100 \%
$$

Berikut ini kriteria untuk penilaian NIM:

TABEL BOBOT PERINGKAT KOMPOSIT NIM

\begin{tabular}{|c|c|c|}
\hline Nilai Komposit & Peringkat & Predikat \\
\hline$>3 \%$ & 1 & Sangat Sehat \\
\hline $2 \%<\mathrm{NIM} \leq 3 \%$ & 2 & Sehat \\
\hline $1,5 \%<\mathrm{NIM} \leq 2 \%$ & 3 & Cukup Sehat \\
\hline $1 \%<\mathrm{NIM} \leq 1,5 \%$ & 4 & Kurang Sehat \\
\hline $\mathrm{NIM} \leq 1 \%$ & 5 & Tidak Sehat \\
\hline
\end{tabular}

Sumber: SE BI No.13/24/DPNP/2011 


\section{Biaya Operasional terhadap Pendapatan Operasional (BOPO)}

Berikut ini menurut SE BI No.13/30/DPNP tanggal 16 Desember 2011 tentang pedoman rasio keuangan rumus BOPO antara lain:

$$
\text { BOPO }=\frac{\text { Beban Operasional }}{\text { Pendapatan Operasional }} \times 100 \%
$$

Berikut ini kriteria untuk penilaian BOPO :

TABEL BOBOT PERINGKAT KOMPOSIT BOPO

\begin{tabular}{|c|c|c|}
\hline Nilai Komposit & Peringkat & Predikat \\
\hline$<90 \%$ & 1 & Sangat Sehat \\
\hline $90 \% \%<$ BOPO $\leq 94 \% \%$ & 2 & Sehat \\
\hline $94 \%<$ BOPO $\leq 96 \%$ & 3 & Cukup Sehat \\
\hline $96 \%<$ BOPO $\leq 100 \%$ & 4 & Kurang Sehat \\
\hline BOPO $100 \%$ & 5 & Tidak Sehat \\
\hline
\end{tabular}

Sumber: SE BI No.13/24/DPNP/2011

\section{3) Penilaian Permodalan (Capita)}

Meliputi penilaian terrhadap tingkat kecukupan permodalan dan pengelolaan permodalan. Penilaian terhadap tingkat kecukupan permodalan dan pengelolaan permodalan dilakukan bank dengan mempertimbangkan tingkat, tren, struktur dan stabilitas dengan memperhatikan kinerja peer grup serta manajemen permodalan bank, baik melalui analisis kuantitatif maupun kualitatif. Salah satu indikator penilaian yang dapat digunakan adalah CAR.

Berikut ini penilaian peringkat komposit CAR antara lain:

\section{$>$ Capital Adequacy Ratio (CAR)}

Fahmi (2014:181) CAR merupakan bagaimana suatu perbankan mampu membiayai aktivitas kegiatan nya dengan modal yang dimiliki.

Berikut ini menurut SE BI No.13/30/DPNP tanggal 16 Desember 2011 tentang pedomaan rasio keuangan rumus CAR antara lain:

$$
\text { CAR }=\frac{\text { Modal }}{\text { ATMR }} \times 100 \%
$$

Berikut ini kriteria untuk penilaian Capital (permodalan):

TABEL BOBOT PERINGKAT KOMPOSIT CAR

\begin{tabular}{|c|c|c|}
\hline Nilai Komposit & Peringkat & Predikat \\
\hline$>12 \%$ & 1 & Sangat Sehat \\
\hline $9 \% \leq C A R<12 \%$ & 2 & Sehat \\
\hline $8 \% \leq C A R<9 \%$ & 3 & Cukup Sehat \\
\hline $5 \%<C A R<8 \%$ & 4 & Kurang Sehat \\
\hline$C A R \leq 6 \%$ & 5 & Tidak Sehat \\
\hline
\end{tabular}

Sumber: SE BI No.13/24/DPNP/2011

\section{Anggapan Dasar}

Riduwan (2019:194) asumsi atau anggapan dasar merupakan teori atau prinsip yang kebenarannya tidak diragukan lagi oleh seorang peneliti. Dalam penelitian ini, 
anggapan dasar penulis adalah penulis mengganggap bahwa akan terjadi adanya perbedaan tingkat kesehatan bank berdasarkan metode RGEC yaitu NPL, LDR, ROA, NIM, BOPO dan CAR dari tahun 2014-2018 yang mengacu pada kategori penilaian peringkat komposit yang terdapat dalam metode pengukuran kesehatan bank diatur dalam Surat Edaran Bank Indonesia Peraturan Bank Indonesia dan Surat Edaran BI No.13/24/DPNP/2011 tentang penilaian tingkat kesehatan bank.

\section{METODE PENELITIAN}

\section{Jenis Penelitian}

Metode yang digunakan dalam penelitian ini adalah metode pendekatan deskriptif kuantitatif yaitu data yang berbentuk angka. Angka yang berhubungan dengan analisis kesehatan bank berdasarkan metode RGEC menggunakan rumus rasio pada PT Bank Rakyat Indonesia (Persero) Tbk. tahun 2014-2018. Metode kuantitatif merupakan jenis penelitian yang menghasilkan penemuan-penemuan yang dapat diperoleh dengan menggunakan prosedur-prosedur statistik atau cara-cara lain dari pengukuran (Sujarweni, 2019:39).

\section{Variabel Penelitian}

Sujarweni (2019:77) variabel penelitian yang dimaksudkan untuk memahami arti setiap variabel penelitian sebelum melakukan analisis, instrument dan sumber pengukuran berasal darimana. Adapun variabel yang digunakan dalam penelitian ini adalah kesehatan perbankan menggunakan metode RGEC

\section{Populasi dan Sampel}

Sugiyono (2018:136) pengertian populasi dan sampel antara lain:

Populasi adalah keseluruhan subjek yang akan diukur yang merupakan unit yang akan diteliti. Populasi dalam penelitian ini adalah laporan keuangan PT Bank Rakyat Indonesia (Persero) Tbk.

Sampel adalah bagian dari jumlah karakteristik yang dimiliki oleh populasi itu sendiri. Sampel yang diambil dari populasi harus mewakili. Sampel dalam penelitian ini adalah laporan keuangan PT Bank Rakyat Indonesia (Persero) Tbk. pada tahun 2014-2018. Maka jenis sampel dalam penelitian ini adalah sampel jenuh. Sampel jenuh adalah sampel yang bila ditambah jumlahnya, tidak akan menambah keterwakilan sehingga tidak akan mempengaruhi nilai informasi yang telah diperoleh atau jumlah populasi sama dengan jumlah sampel yang akan diteliti (Sugiyono, 2018:144).

\section{Sumber data}

Sumber data yang digunakan adalah data sekunder yaitu Sumber yang tidak langsung memberikan data kepada pengumpul data. Maka sumber data dalam penelitian ini adalah data sekunder berupa laporan keuangan tahun 2014-2018 PT Bank Rakyat Indonesia (Persero) Tbk.

\section{Teknik Pengumpulan Data}

Adapun teknik pengumpulan data yang digunakan dalam penelitian ini adalah:

Studi pustaka : Suryabrata (2011:35) teknik pengumpulan data dengan mengadakan studi penelaahan terhadap buku-buku, literatur-literatur, catatan-catatan dan laporanlaporan yang ada hubungannya dengan masalah yang dipecahkan.

Teknik dokumen: Sugiyono (2018:476) catatan peristiwa yang sudah berlalu, dokumen berbentuk tulisan, gambar atau karya-karya monumental dari seseorang. 
Adapun dokumen yang digunakan adalah berupa laporan keuangan tahun 20142018 PT Bank Rakyat Indonesia (Persero) Tbk.

\section{Teknik Analisis Data}

Sujarweni (2019:121) teknik analisis data merupakan tata cara melaksanakan analisis terhadap data dengan tujuan mengelola data tersebut untuk menjawab rumusan masalah. Teknik analisis yang digunakan dalam penelitian ini adlaha deskriptif kuantitatif. Penelitian yang tujuan utama nya untuk memberikan gambaran atau deskripsi tentang sesuatu keadaan secara objektif. Dalam penelitian ini penulis akan menghitung dan menggambarkan serta membandingkan kesehatan bank melalui variabel yang satu dengan variabel yang lainnya berdasarkan hasil analisis data menggunakan metode RGEC:

a. Aspek Risk Profile menggunakan resiko likuiditas yaitu Loan to Deposit Ratio ( $L D R$ ) dan resiko kredit Non Perfoming Loan (NPL)

b. Aspek Earning (rentabilitas) menggunakan rasio $R O A, N I M$ dan BOPO

c. Aspek Capital (permodalan) menggunakan Capital Adequacy Ratio (CAR)

Adapun langkah-langkah yang digunakan untuk mendeskripsikan hasil analisis data dilakukan dengan langkah-langkah sebagai berikut:

1) Pengumpulan data dari objek penelitian berupa laporan keuangan tahun 20142018 PT Bank Rakyat Indonesia (Persero) Tbk.

2) Menghitung kesehatan bank berdasarkan metode RGEC yaitu Risk Profile menggunakan resiko likuiditas LDR dan resiko kredit NPL, Earning (rentabilitas) menggunakan ROA, BOPO dan NIM serta Capital (permodalan) menggunakan CAR

3) Hasil analisis tersebut akan disesuaikan dengan kriteria/tolak ukur yang telah ditetapkan oleh Bank Indonesia dalam menentukan kesehatan bank yaitu metode RGEC

4) Menetapkan kategori kesehatan bank berdasarkan penilaian peringkat komposit dalam metode RGEC dalam PBI No.13/1/PBI/2011 dan SE BI No.13/24/DPNP/2011 tentang kesehatan bank yang meliputi kelima peringkat diantaranya:

Peringkat 1 : Mencerminkan kondisi bank yang secara umum sangat sehat sehingga dinilai sangat mampu menghadapi pengaruh negatif yang signifikan dari perubahan kondisi bisnis dan factor eksternal lainnya.

Peringkat 2: Mencerminkan kondisi bank yang secara umum sehat sehingga dinilai mampu menghadapi pengaruh negatif yang signifikan dari perubahan kondisi bisnis dan factor eksternal lainnya.

Peringkat 3: Mencerminkan kondisi bank yang secara umum cukup sehat sehingga dinilai cukup mampu menghadapi pengaruh negatif yang signifikan dari perubahan kondisi bisnis dan factor eksternal lainnya.

Peringkat 4: Mencerminkan kondisi bank yang secara umum kurang sehat sehingga dinilai kurang mampu menghadapi pengaruh negatif yang signifikan dari perubahan kondisi bisnis dan factor eksternal lainnya.

Peringkat 5: Mencerminkan kondisi bank yang secara umum tidak sehat sehingga dinilai mampu menghadapi pengaruh negatif yang signifikan dari perubahan kondisi bisnis dan faktor eksternal lainnya. 


\section{HASIL PENELITIAN}

1) Aspek penilaian Risk Profile (Profil resiko)

a. Loan to Deposit Ratio (LDR)

Dihitung menggunakan rumus:

$$
L D R=\frac{\text { Total Kredit }}{\text { DP3 }} x 100 \%
$$

Berikut ini adalah hasil dari perhitungan LDR:

TABEL HASIL PERHITUNGAN LDR

(Dalam jutaan rupiah)

\begin{tabular}{|c|c|r|c|c|c|}
\hline \multirow{2}{*}{ Periode } & \multirow{2}{*}{ Total Kredit } & \multicolumn{2}{|c|}{ Dana Pihak Ketiga (DP3) } & \multirow{2}{*}{$\begin{array}{c}\text { Hasil LDR } \\
\text { (\%) }\end{array}$} \\
\cline { 3 - 5 } & & Giro & Tabungan & $\begin{array}{c}\text { Deposito } \\
\text { Berjangka }\end{array}$ & \\
\hline 2014 & 495.097 .288 & 90.052 .180 & 236.394 .994 & 295.874 .672 & 79,56 \\
2015 & 564.480 .538 & 114.367 .088 & 272.470 .992 & 282.157 .299 & 84,38 \\
2016 & 643.470 .975 & 142.546 .863 & 303.270 .288 & 308.709 .223 & 85,28 \\
2017 & 718.982 .668 & 147.435 .604 & 349.440 .873 & 344.779 .973 & 85,42 \\
2018 & 820.010 .157 & 180.669 .095 & 387.179 .625 & 376.420 .017 & 86,84 \\
\hline
\end{tabular}

Sumber: Data sekunder (diolah tahun 2020)

Berdasarkan data tabel diatas maka dapat dihitung LDR sebagai berikut:

Tahun $2014:$ LDR $=\frac{495.097 .288}{622.321 .846} \times 100 \%=79,56 \%$

Tahun $2015:$ LDR $=\frac{564.480 .538}{668.995 .379} \times 100 \%=84,38 \%$

Tahun 2016: $\mathrm{LDR}=\frac{643.470 .975}{754.526 .374} \times 100 \%=85,28 \%$

Tahun 2017: $\mathrm{LDR}=\frac{718.982 .668}{841.656 .450} \times 100 \%=85,42 \%$

Tahun2018: $\mathrm{LDR}=\frac{820.010 .157}{944.268 .737} \times 100 \%=86,84 \%$

Untuk lebih jelas berikut ini tabel nilai peringkat komposit rasio LDR:

TABEL NILAI PERINGKAT KOMPOSIT LDR

\begin{tabular}{|c|c|c|c|}
\hline Periode & LDR (\%) & Peringkat & Keterangan \\
\hline 2014 & 79,56 & 2 & Sehat \\
2015 & 84,38 & 2 & Sehat \\
2016 & 85,28 & 2 & Sehat \\
2017 & 85,42 & 2 & Sehat \\
2018 & 86,84 & 3 & Cukup Sehat \\
\hline
\end{tabular}

Sumber: Data sekunder (diolah tahun 2020)

b. Non Perfoming Loan (NPL)

Dihitung menggunakan rumus:

$$
\text { NPL }=\frac{\text { Kredit Bermasalah }}{\text { Total Kredit }} \times 100 \%
$$


Berikut ini adalah hasil perhitungan NPL:

TABEL HASIL PERHITUNGAN NPL

(Dalam jutaan rupiah)

\begin{tabular}{|c|c|c|c|c|c|}
\hline \multirow[b]{2}{*}{ Periode } & \multicolumn{3}{|c|}{ Kredit Bermasalah } & \multirow[b]{2}{*}{ Total Kredit } & \multirow{2}{*}{$\begin{array}{c}\text { Hasil NPL } \\
(\%)\end{array}$} \\
\hline & $\begin{array}{l}\text { Kurang } \\
\text { Lancar }\end{array}$ & Diragukan & Macet & & \\
\hline 2014 & 1.043 .082 & 1.201 .996 & 3.974 .665 & 495.097 .288 & 1,26 \\
\hline 2015 & 1.160 .311 & 1.224 .930 & 4.213 .597 & 564.480 .538 & 1,17 \\
\hline 2016 & 1.056 .103 & 1.128 .476 & 4.605 .802 & 643.470 .975 & 1,06 \\
\hline 2017 & 1.290 .701 & 1.408 .731 & 5.216 .546 & 718.982 .668 & 1,10 \\
\hline 2018 & 1.573 .704 & 1.777 .038 & 6.280 .707 & 820.010 .157 & 1,17 \\
\hline
\end{tabular}

Sumber: Data sekunder (diolah tahun 2020)

Berdasarkan data tabel diatas maka dapat dihitung Non Performing Loan (NPL) sebagai berikut:

Tahun $2014: \mathrm{NPL}=\frac{6.219 .743}{495.097 .288} \times 100 \%=1,26 \%$

Tahun $2015: \mathrm{NPL}=\frac{6.598 .838}{564.480 .538} \times 100 \%=1,17 \%$

Tahun $2016: \mathrm{NPL}=\frac{6.790 .381}{643.470 .975} \times 100 \%=1,06 \%$

Tahun $2017:$ NPL $=\frac{7.915 .978}{718.982 .668} \times 100 \%=1,10 \%$

Tahun $2018: \mathrm{NPL}=\frac{9.631 .449}{820.010 .157} \times 100 \%=1,17 \%$

Untuk lebih jelas berikut ini tabel nilai peringkat komposit rasio LDR:

TABEL NILAI PERINGKAT KOMPOSIT NPL

\begin{tabular}{|c|c|c|c|}
\hline Periode & NPL (\%) & Peringkat & Keterangan \\
\hline 2014 & 1,26 & 1 & Sangat Sehat \\
2015 & 1,17 & 1 & Sangat Sehat \\
2016 & 1,06 & 1 & Sangat Sehat \\
2017 & 1,1 & 1 & Sangat Sehat \\
2018 & 1,17 & 1 & Sangat Sehat \\
\hline
\end{tabular}

Sumber: Data sekunder (diolah tahun 2020)

2) Aspek penilaian Earning (Rentabilitas)

a. Return On Asset (ROA)

Dihitung dengan rumus:

$$
\mathrm{ROA}=\frac{\text { Laba sebelum pajak }}{\text { Rata }- \text { rata total asset }} x 100 \%
$$


Berikut ini hasil perhitungan ROA antara lain:

TABEL HASIL PERHITUNGAN ROA

(Dalam Jutaan Rupiah)

\begin{tabular}{|c|c|c|c|}
\hline Periode & $\begin{array}{c}\text { Laba Sebelum } \\
\text { Pajak }\end{array}$ & $\begin{array}{c}\text { Rata-Rata } \\
\text { Total Aset }\end{array}$ & Hasil $\boldsymbol{R O A}(\%)$ \\
\hline 2014 & 30.804 .112 & 801.984 .190 & 3,84 \\
2015 & 32.494 .018 & 878.426 .312 & 3,70 \\
2016 & 34.047 .035 & 1.004 .801 .673 & 3,39 \\
2017 & 37.023 .236 & 1.127 .447 .489 & 3,28 \\
2018 & 41.753 .694 & 1.296 .898 .292 & 3,22 \\
\hline
\end{tabular}

Sumber: Data sekunder (diolah tahun 2020)

Berdasarkan data tabel diatas maka dapat dihitung Return On Asset (ROA) sebagai berikut:

Tahun $2014: \mathrm{ROA}=\frac{30.804 .112}{801.984 .190} \times 100 \%=3,84 \%$

Tahun $2015: \mathrm{ROA}=\frac{32.494 .018}{878.426 .312} \times 100 \%=3,70 \%$

Tahun $2016: \mathrm{ROA}=\frac{34.047 .035}{1.004 .801 .673} \times 100 \%=3,39 \%$

Tahun $2017: \mathrm{ROA}=\frac{37.023 .236}{1.127 .447 .489} \times 100 \%=3,28 \%$

Tahun $2018: \mathrm{ROA}=\frac{41.753 .694}{1.296 .898 .292} \times 100 \%=3,22 \%$

Untuk lebih jelas berikut ini tabel nilai peringkat komposit rasio ROA:

TABEL NILAI PERINGKAT KOMPOSIT ROA

\begin{tabular}{|c|c|c|c|}
\hline Periode & ROA (\%) & Peringkat & Keterangan \\
\hline 2014 & 3,84 & 1 & Sangat Sehat \\
2015 & 3,7 & 1 & Sangat Sehat \\
2016 & 3,39 & 1 & Sangat Sehat \\
2017 & 3,28 & 1 & Sangat Sehat \\
2018 & 3,22 & 1 & Sangat Sehat \\
\hline
\end{tabular}

Sumber: Data sekunder (diolah tahun 2020)

b. Net Interest Margin (NIM)

Dihitung dengan rumus:

$$
N I M=\frac{\text { Pendapatan bunga bersih }}{\text { Rata }- \text { rata aktiva produktif }} x 100 \%
$$

Berikut ini hasil perhitungan NIM antara lain: 
TABEL HASIL PERHITUNGAN NIM

(Dalam Jutaan Rupiah)

\begin{tabular}{|c|r|r|c|}
\hline Periode & $\begin{array}{c}\text { Pendapatan } \\
\text { Bunga Bersih }\end{array}$ & $\begin{array}{c}\text { Rata-Rata } \\
\text { Aset Produktif }\end{array}$ & $\begin{array}{c}\text { Hasil NIM } \\
(\%)\end{array}$ \\
\hline 2014 & 51.442 .410 & 728.094 .000 & 7,07 \\
2015 & 58.279 .767 & 781.931 .000 & 7,45 \\
2016 & 65.439 .190 & 991.719 .000 & 6,60 \\
2017 & 73.018 .094 & 1.128 .476 .000 & 6,47 \\
2018 & 77.665 .772 & 1.178 .512 .000 & 6,59 \\
\hline
\end{tabular}

Sumber: Data sekunder (diolah tahun2020)

Berdasarkan data tabel diatas maka dapat dihitung NIM sebagai berikut:

Tahun $2014: \mathrm{NIM}=\frac{51.442 .410}{728.094 .000} \times 100 \%=7,07 \%$

Tahun $2015: \mathrm{NIM}=\frac{58.279 .767}{781.931 .000} \times 100 \%=7,45 \%$

Tahun $2016: \mathrm{NIM}=\frac{65.439 .190}{991.719 .000} \times 100 \%=6,60 \%$

Tahun $2017: \mathrm{NIM}=\frac{73.018 .094}{1.128 .476 .000} \times 100 \%=6,47 \%$

Tahun $2018: \mathrm{NIM}=\frac{77.665 .772}{1.178 .512 .000} \times 100 \%=6,59 \%$

Untuk lebih jelas berikut ini tabel nilai peringkat komposit rasio NIM:

\section{TABEL NILAI PERINGKAT KOMPOSIT NIM}

\begin{tabular}{|c|c|c|c|}
\hline Periode & NIM (\%) & Peringkat & Keterangan \\
\hline 2014 & 7,07 & 1 & Sangat Sehat \\
2015 & 7,45 & 1 & Sangat Sehat \\
2016 & 6,6 & 1 & Sangat Sehat \\
2017 & 6,47 & 1 & Sangat Sehat \\
2018 & 6,59 & 1 & Sangat Sehat \\
\hline
\end{tabular}

Sumber: Data sekunder (diolah tahun2020)

c. Biaya Operasional terhadap Pendapatan Operasional (BOPO)

Dihitung dengan rumus:

$$
\text { BOPO }=\frac{\text { Beban Operasional }}{\text { Pendapatan Operasional }} x 100 \%
$$

Berikut ini hasil perhitungan BOPO antara lain: 
TABEL HASIL PERHITUNGAN BOPO

(Dalam Jutaan Rupiah)

\begin{tabular}{|c|c|c|c|}
\hline Periode & $\begin{array}{c}\text { Beban } \\
\text { Operasional }\end{array}$ & $\begin{array}{c}\text { Pendapatan } \\
\text { Operasional }\end{array}$ & $\begin{array}{c}\text { Hasil Bopo } \\
(\%)\end{array}$ \\
\hline 2014 & 32.434 .634 & 70.688 .808 & 45,88 \\
2015 & 40.175 .901 & 70.688 .808 & 56,83 \\
2016 & 48.960 .436 & 82.727 .047 & 59,18 \\
2017 & 55.867 .954 & 92.289 .381 & 60,54 \\
2018 & 60.311 .047 & 101.091 .202 & 59,66 \\
\hline
\end{tabular}

Sumber: Data sekunder (diolah tahun 2020)

Berdasarkan data tabel diatas maka dapat dihitung Beban Operasional terhadap Pendapatan Operasional (BOPO) sebagai berikut:

Tahun $2014:$ BOPO $=\frac{32.434 .634}{70.688 .808} \times 100 \%=45,88 \%$

Tahun $2015:$ BOPO $=\frac{40.175 .901}{70.688 .808} x 100 \%=56,83 \%$

Tahun $2016:$ BOPO $=\frac{48.960 .436}{82.727 .047} \times 100 \%=59,18 \%$

Tahun $2017:$ BOPO $=\frac{55.867 .954}{92.289 .381} \times 100 \%=60,54 \%$

Tahun $2018:$ BOPO $=\frac{60.311 .047}{101 \cdot 091.202} \times 100 \%=59,66 \%$

Untuk lebih jelas berikut ini tabel nilai peringkat komposit rasio BOPO:

TABEL NILAI PERINGKAT KOMPOSIT BOPO

\begin{tabular}{|c|c|c|c|}
\hline Periode & BOPO (\%) & Peringkat & Keterangan \\
\hline 2014 & 45,88 & 1 & Sangat Sehat \\
2015 & 56,83 & 1 & Sangat Sehat \\
2016 & 59,18 & 1 & Sangat Sehat \\
2017 & 60,54 & 1 & Sangat Sehat \\
2018 & 59,66 & 1 & Sangat Sehat \\
\hline
\end{tabular}

Sumber: Data sekunder (diolah tahun2020)

3) Aspek Capital (permodalan)

Dihitung menggunakan rumus:

$$
\text { CAR }=\frac{\text { Modal Bank }}{\text { ATMR }} x 100 \%
$$

Berikut ini hasil perhitungan CAR antara lain: 
TABEL HASIL PERHITUNGAN CAR

(Dalam Jutaan Rupiah)

\begin{tabular}{|c|r|c|c|}
\hline Periode & \multicolumn{1}{|c|}{ Modal Bank } & ATMR & Hasil CAR (\%) \\
\hline 2014 & 97.705 .834 & 468.182 .076 & 20,87 \\
2015 & 113.127 .179 & 537.074 .938 & 21,06 \\
2016 & 147.534 .097 & 623.857 .728 & 23,65 \\
2017 & 168.007 .778 & 704.515 .985 & 23,85 \\
2018 & 185.275 .331 & 818.608 .240 & 22,63 \\
\hline
\end{tabular}

Sumber: Data sekunder (diolah tahun2020)

Berdasarkan data tabel diatas maka dapat dihitung Capital Adequacy Ratio (CAR) sebagai berikut:

Tahun $2014:$ CAR $=\frac{97.705 .834}{468.182 .076} \times 100 \%=20,87 \%$

Tahun $2015:$ CAR $=\frac{113.127 .179}{537.074 .938} \times 100 \%=21,06 \%$

Tahun $2016:$ CAR $=\frac{147.534 .097}{623.857 .728} \times 100 \%=23,65 \%$

Tahun $2017:$ CAR $=\frac{168.007 .778}{704.515 .985} \times 100 \%=23,65 \%$

Tahun $2018:$ CAR $=\frac{185.275 .331}{818.608 .240} \times 100 \%=22,63 \%$

Untuk lebih jelas berikut ini tabel nilai peringkat komposit rasio CAR

TABEL NILAI PERINGKAT KOMPOSIT CAR

\begin{tabular}{|c|c|c|c|}
\hline Periode & CAR (\%) & Peringkat & Keterangan \\
\hline 2014 & 20,87 & 1 & Sangat Sehat \\
2015 & 21,06 & 1 & Sangat Sehat \\
2016 & 23,65 & 1 & Sangat Sehat \\
2017 & 23,85 & 1 & Sangat Sehat \\
2018 & 22,63 & 1 & Sangat Sehat \\
\hline
\end{tabular}

Sumber: Data sekunder (diolah tahun2020)

\section{E. PEMBAHASAN}

Metode penilaian kesehatan bank selalu berubah untuk penyesuaian kondisi dan situasi perbankan sehingga penilaian kesehatan bank lebih efektif. Bank Indonesia sebagai pembina dan pengawas perbankan di Indonesia menetapkan Peraturan Bank Indonesia No. 13/1/PBI/2011 dan Surat Edara Bank Indonesia No/13/24/DPNP/2011 tentang penilaian kesehatan bank umum dengan menggunakan metode RGEC (Risk Profile, Good Corporate Governance, Earnings, Capital).

Penelitian yang dilakukan oleh Lasta dkk (2014:1) menjelaskan bahwa tingkat kesehatan BRI pada tahun 2011 sampai dengan 2013 yang diukur dengan metode RGEC secara keseluruhan dapat dikatakan bank yang sehat. Risk Profile dinilai dengan NPL, IRR, LDR LAR, Cash Ratio telah menggambarkan pengelolaan risiko yang telah dilaksanakan dengan baik. Good Corporate Governance sudah memiliki dan menerapkan tata kelola perusahaan dengan sangat baik. Earning dinlai dengan 
ROA dan NIM mengalami kenaikan yang mmenunjukkan bertambahnya jumlah asset yang diikuti bertambahnya juga keuntungan. Dan Capital dinilai menggunakan CAR peneliti sudah membuktikan bahwa memiliki Capital yang baik yaitu memiliki CAR diatas $8 \%$.

Penelitian kesehatan bank yang serupa juga dilakukan oleh Saladin dan Hendri (2017:1). Penelitian yang menunjukkan uji beda bahwa secara statistik terdapat perbedaan yang signifikan antara Bank Mandiri dan Bank BCA dilihat berdasarkan NPL, ROA dan BOPO dan tidak terdapat perbedaan yang signifikan antara Bank Mandiri dan Bank BCA dilihat berdasarkan LDR, ROE, NIM dan CAR. Rata-rata rasio NPL, ROA, ROE, NIM, BOPO dan CAR tahun 2011-2015 Bank BCA lebih baik dibandingkan Bank Mandiri dan hanya rata-rata rasio LDR bank Mandiri lebih baik dibandingkan Bank BCA. Dalam waktu 5 tahun baik Bank Mandiri dan Bank BCA rasio NPL, LDR, ROA, ROE, NIM , BOPO dan CAR memperoleh predikat yang sangat sehat.

Penelitian yang dilakukan oleh Candra Dewi (2018:1595) menunjukkan bahwa BTN periode 2014 mendapatkan predikat Cukup Sehat dan pada periode 2015-2016 meningkat dengan memperoleh predikat Sehat. Hal ini mencerminkan Bank Tabungan Negara dapat meningkatkan dan menjaga tingkat kesehatan bank.

Dalam penelitian ini mengukur kesehatan bank dengan metode RGEC pada PT Bank Rakyat Indonesia (Persero) Tbk. secara keseluruhan sudah sangat sehat jika ditinjau dari aspek penilaian RGEC:

1. Aspek Penilaian Risk Profile (resiko profil)

a. Resiko Likuiditas (LDR)

Dilihat dari resiko likuiditas yaitu menggunakan rasio Loan to Deposit Ratio (LDR) secara keseluruhan kesehatan PT Bank Rakyat Indonesia (Persero) Tbk. tahun 2014-2017 sudah dapat dikatakan sehat. Ditunjukkan dengan hasil LDR dari tahun 2014-2017 berturut-turut adalah 79,56\%, 84,38\%, 85,28\%, 85,42\% dan $86,84 \%$. Setelah disesuaikan dengan peringkat komposit yang ditentukan oleh Bank Indonesia yang diatur dalam SE BI No.13/24/DPNP/2011 Ditahun 2014-2017 LDR berada di peringkat 2 yaitu bank yang sehat, artinya PT Bank Rakyat Indonesia (Persero) Tbk. dinilai mampu menghadapi pengaruh negatif yang signifikan dari perubahan kondisi bisnis dan faktor eksternal lainnya. Dan ditahun 2018 LDR berada di peringkat 3 yaitu bank yang cukup sehat, artinya bahwa PT Bank Rakyat Indonesia (Persero) Tbk. sudah cukup baik dan sudah baik dalam hal mengelola dan memenuhi kebutuhan nasabah pada saat mengambil dananya dan menyalurkan kredit (pinjaman) kepada peminjam (debitur).

b. Resiko Kredit (NPL)

Dilihat dari resiko kredit yaitu menggunakan rasio Non Performing Ratio (NPL) secara keseluruhan kesehatan PT Bank Rakyat Indonesia (Persero) Tbk. tahun 2014-2018 sudah dapat dikatakan sangat sehat. Ditunjukkan dengan hasil NPL dari tahun 2014-2018 berturut-turut adalah 1,26\%, 1,17\%, 1,06\%, 1,10\% dan $1,17 \%$. Setelah disesuaikan dengan peringkat komposit yang ditentukan oleh Bank Indonesia yang diatur dalam SE BI No.13/24/DPNP/2011 Ditahun 20142018 NPL berada di peringkat 1 yaitu dengan kategori bank yang sangat sehat, artinya bahwa PT Bank Rakyat Indonesia (Persero) Tbk. sudah sangat baik dalam mengelola kredit bermasalah dari keseluruhan kredit yang diberikan. 
2. Aspek Penilaian Earning (Rentabilitas)

a. Return On Asset (ROA)

Dilihat dari rasio Return On Asset (ROA) secara keseluruhan kesehatan PT Bank Rakyat Indonesia (Persero) Tbk. tahun 2014-2018 sudah dapat dikatakan sangat sehat. Ditunjukkan dengan hasil ROA dari tahun 2014-2018 berturutturut adalah 3,84\%, 3,70\%, 3,39\%, 3,28\% dan 3,22\%. Setelah disesuaikan dengan peringkat komposit yang ditentukan oleh Bank Indonesia yang diatur dalam SE BI No.13/24/DPNP/2011 Ditahun 2014-2018 ROA berada di peringkat 1 yaitu dengan kategori bank yang sangat sehat, artinya bahwa PT Bank Rakyat Indonesia (Persero) Tbk. sudah sangat baik dalam hal menghasilkan laba atau profit.

b. Net Interest Margin (NIM)

Dilihat dari Net Interset Margin (NIM) secara keseluruhan kesehatan PT Bank Rakyat Indonesia (Persero) Tbk. tahun 2014-2018 sudah dapat dikatakan sangat sehat. Ditunjukkan dengan hasil NIM dari tahun 2014-2018 berturut-turut adalah 7,07\%, 7,45\%,6,60\%,6,47\% dan 6,59\%. Setelah disesuaikan dengan peringkat komposit yang ditentukan oleh Bank Indonesia yang diatur dalam SE BI No.13/24/DPNP/2011 Ditahun 2014-2018 NIM berada di peringkat 1 yaitu dengan kategori bank yang sangat sehat, artinya bahwa PT Bank Rakyat Indonesia (Persero) Tbk. sudah sangat baik dalam hal pengelolaan asset/aktiva produktif sehingga bisa menghasilkan laba bersih.

c. Beban Operasional terhadap Pendapatan Operasional (BOPO)

Dilihat dari BOPO secara keseluruhan kesehatan PT Bank Rakyat Indonesia (Persero) Tbk. tahun 2014-2018 sudah dapat dikatakan sangat sehat. Ditunjukkan dengan hasil BOPO dari tahun 2014-2018 berturut-turut adalah 45,88\%, 56,83\%, 59,18\%, 60,54\% dan 59,66\%. Setelah disesuaikan dengan peringkat komposit yang ditentukan oleh Bank Indonesia yang diatur dalam SE BI No.13/24/DPNP/2011 Ditahun 2014-2018 BOPO berada di peringkat 1 yaitu dengan kategori bank yang sangat sehat, artinya bahwa PT Bank Rakyat Indonesia (Persero) Tbk. sudah sangat baik dalam hal efisiensi bank dalam penggunaan kegiatan nya.

3. Aspek Penilaian Capital (Permodalan)

a. Capital Adequacy Ratio (CAR)

Dilihat dari Capital Adequacy Ratio (CAR) secara keseluruhan kesehatan PT Bank Rakyat Indonesia (Persero) Tbk. tahun 2014-2018 sudah dapat dikatakan sangat sehat. Ditunjukkan dengan hasil CAR dari tahun 2014-2018 berturutturut adalah 20,87\%, 21,06\%, 23,65\%, 23,85\% dan 22,63\%. Setelah disesuaikan dengan peringkat komposit yang ditentukan oleh Bank Indonesia yang diatur dalam SE BI No.13/24/DPNP/2011 Ditahun 2014-2018 CAR berada di peringkat 1 yaitu dengan kategori bank yang sangat sehat, artinya bahwa PT Bank Rakyat Indonesia (Persero) Tbk. pada tahun 2018 sudah mampu dalam hal mencari dana atau menyediakan dana guna memenuhi kegiatan nya dan mengatasi resiko kerugian. 


\section{F. KESIMPULAN DAN SARAN}

1) Kesimpulan

Berdasarkan rumusan masalah, hasil penelitian dan pembahasan yang telah dilakukan pada PT Bank Rakyat Indonesia (Persero) Tbk. periode tahun 2014-2018 yang mengacu pada PBI No.13/1/PBI/2011 dan SE BI No.13/24/DPNP/2011 dalam metode RGEC maka dapat ditarik kesimpulan bahwa kesehatan bank tersebut adalah sebagai berikut:

a. Aspek Penilaian Risk Profile (resiko profil)

Ditinjau dari Resiko Likuiditas yaitu rasio Loan to Deposit Ratio (LDR) periode tahun 2014-2017 berada pada kategori bank yang SEHAT, artinya PT Bank Rakyat Indonesia (Persero) Tbk. dinilai mampu menghadapi pengaruh negatif yang signifikan dari perubahan kondisi bisnis dan faktor eksternal lainnya. Dan pada periode tahun 2018 rasio LDR berada dalam kategori bank yang CUKUP SEHAT, artinya dinilai cukup mampu menghadapi pengaruh negatif yang signifikan dari perubahan kondisi bisnis dan faktor eksternal lainnya.

Ditinjau dari Resiko Kredit yaitu rasio Non Performing Ratio (NPL) periode tahun 2014-2018 berada pada kategori bank yang SANGAT SEHAT, artinya PT Bank Rakyat Indonesia (Persero) Tbk. dinilai sangat mampu menghadapi pengaruh negatif yang signifikan dari perubahan kondisi bisnis dan faktor eksternal lainnya.

b. Aspek Earning (Rentabilitas)

Ditinjau dari rasio Return On Asset (ROA), Net Interest Margin (NIM) dan Beban Operasional terhadap Pendapatan Operasional (BOPO) periode tahun 20142018 berada pada kategori bank yang SANGAT SEHAT, artinya PT Bank Rakyat Indonesia (Persero) Tbk. dinilai sangat mampu menghadapi pengaruh negatif yang signifikan dari perubahan kondisi bisnis dan faktor eksternal lainnya.

c. Aspek Capital (Permodalan)

Ditinjau dari CAR periode tahun 2014-2018 berada pada kategori bank yang SANGAT SEHAT, artinya PT Bank Rakyat Indonesia (Persero) Tbk. dinilai sangat mampu menghadapi pengaruh negatif yang signifikan dari perubahan kondisi bisnis dan faktor eksternal lainnya.

2) Saran

a. Pada rasio LDR sebaiknya PT Bank Rakyat Indonesia (Persero) Tbk. mengurangi penyaluran kredit sehingga menyebabkan rasio LDR yang semakin kecil atau semakin sehat setiap tahunnya, tetapi jangan sampai terdapat dana yang menganggur yang menyebabkan berkurangnya pendapatan bank. Lebih baik untuk menghindari dana yang menganggur Dana Pihak Ketiga (DPK) juga disalurkan berupa Sertifikat Bank Indonesia (SBI), Penyertaan maupun Obligasi. Dengan cara penyaluran kredit dikurangi oleh bank tentu akan lebih likuiditas dalam menghadapi resiko kredit yang akan terjadi.

b. Pada rasio NPL, ROA, NIM, BOPO dan CAR PT Bank Rakyat Indonesia (Persero) Tbk. tetap selalu menjaga kestabilan, kepercayaan dan meyakinkan kepada nasabah serta stakeholder yang akan menanamkan modalnya di PT Bank Rakyat Indonesia (Persero) Tbk.

c. Bagi peneliti selanjutnya agar dapat memperbanyak indikator penilaian kesehatan bank untuk melihat secara luas kesehatan bank dalam seluruh aspek penilaian yang telah ditentukan oleh Bank Indonesia 


\section{DAFTAR PUSTAKA}

Bank Indonesia. (1998). Undang-Undang Nomor 10 tahun 1998 tentang perbankan. Jakarta.

Bank Indonesia. (2011). Penilaian Tingkat Kesehatan Bank. Surat Edaran No.13/24/DPNP/2011.

Bank Indonesia. (2012). Transparansi dan Publikasi Laporan Bank. Peraturan Bank Indonesia No.14/14/PBI/2012.

Bachtiar, S. (2019). Analisis Rasio Likuiditas, Solvabilitas dan Profitabilitas pada PT. Bank Rakyat Indonesia (Persero) Tbk. Jakarta Stock Exchange. PAY Jurnal Keuangan dan Perbankan, 1(1), 12.

Bank Rakyat Indonesia. (2020) Sejarah Bank BRI. Https://id.wikipedia.org/wiki/Bank_Rakyat_Indonesia

Candradewi, I. A. (2018). Penilaian Tingkat Kesehatan Bank Metode RGEC Pada PT. Bank Tabungan Negara (persero) Tbk Periode 2014-2016. E-Jurnal Manajemen Unud, 7, 1595.

Fahmi, Irham. (2014). Analisis Laporan Keuangan, cetakan kedua.Bandung:Alfabetta

Hendri, Edduar dan Saladin Hendri. (2017). Analisis Komparatif Tingkat Kesehatan Bank Berdasarkan Metode REC (Studi pada PT bank Mandiri Tbk dan Pt BCA Tahun 2011-2015). Jurnal Media Wahana Ekonomika, 13, 1.

Hery. (2015). Analisis Laporan Keuangan. Jakarta: CAPS (Center for Academic Publishing Service).

Ikatan Bankir Indonesia. (2016). Manajemen Kesehatan Bank Berbasis Resiko. Jakarta: PT. Gramedia Pustaka Utama.

Ismail. (2010). Akuntansi Bank. Jakarta: Prenadamedia Group.

Kasmir. (2018). Analisis Laporan Keuangan. Jakarta: Rajawali Pers.

Lasta, Heidy Arrida et al. (2014). Analisis tingkat Kesehatan Bank dengan Menggunakan Pendekatan RGEC (Studi pada PT Bank Rakyat Indonesia Tbk. periode 2011-2013). Jurnal Administrasi Bisnis, 13(2), 6.

Purba, Kuras. (2019). Manajemen Perbankan. Bandung: Yrama Widya.

Riduwan. (2019). Belajar Mudah Penelitian untuk Guru, Karyawan, dan Peneliti Pemula. Bandung: Alfhabeta

Sugiyono. (2018). Metode Penelitian Bisnis. Bandung: Alfabetta.

Sujarweni, Wiratna. (2019). Metodologi Penelitian Bisnis Ekonomi. Yogyakarta: PT. Pustaka Baru.

Suryabrata, Sumadi. (2011). Metodologi Penelitian. Jakarta: Raja Grafindo Persada 